\title{
The complexity of monumentality in Melanesia: Mixed messages from Vanuatu
}

\author{
Stuart Bedford
}

\section{Introduction}

This paper revisits the concept of monumentality through the lens of grand communal ceremonies on three separate islands, with contrasting chiefly systems, in the archipelago of Vanuatu (Figure 5.1). One is the island of Malakula in the north where substantial stone structures associated with a range of ceremonies can be found right across the landscape. Further south on Efate the use of stone is limited but grand ceremony and monumentality is spectacularly demonstrated in the archaeological record. Lastly, large ceremonies involving thousands of people occur on a regular basis on the island of Tanna in the south, yet the material remains of such events are almost completely absent (Bonnemaison 1994). This striking variance across a single archipelago leads to some questions regarding the whole concept and significance of monumentality (Ballard and Wilson 2014) and particularly to its importance in relation to processes of social transformation in the Pacific. However, it needs to be emphasised that the wider debate is somewhat handicapped by the fact that the study of monumentality across the broader Pacific is extremely uneven in its coverage, at least in archaeological focus, in terms of both even basic information and a lack of targeted research (Walter and Sheppard 2006). While the trajectory of sociopolitical complexity and its associated proxies have been tracked on almost literally every major Polynesian island group, along with many in Micronesia, the archaeology of social systems of the South-West Pacific are rare (Allen 1985; Garanger 1972; Irwin 1985; Sand 1995; Spriggs 1986) and specifically those associated with ritual architecture, or monumentality generally, remain remarkably few (Bickler 2004; Byrne 2013; Field 2004; Sand 1995; Spriggs 1986; Thomas 2009; Walter and Sheppard 2006).

Pacific Island societies have long played a special role in influencing Western theoretical discourse relating to the form and development of sociopolitical structures and their evolution on a world-scale (Kirch 1984, 2010; Spriggs 2008). Right from the very beginnings of European and Pacific encounters, as the accounts of the early explorers surfaced in Europe, debate was inspired regarding the nature of human society (Smith 1989, 1992). It did not take long for Pacific societies to be drafted into theories relating to the emerging 19th-century ladder-like structures of social evolution as exemplars of the lower rungs (Golson 1977). When the region was carved up on maps into Melanesia, Micronesia and Polynesia by the French explorer Dumont d'Urville in 1832, insidious racial categories became formalised (Dumont d'Urville 2003). Apparent forms of social organisation were particularly influential in the ordering of a region's position on the 
evolutionary scale. Polynesians at the apex were admired for having sophisticated sociopolitical structures and light skin colour, while at the other end of the scale, Melanesians were described as having 'no governing bodies, no laws, and no formal religious practices' concomitant with their darker skin colour (Dumont d'Urville 2003).

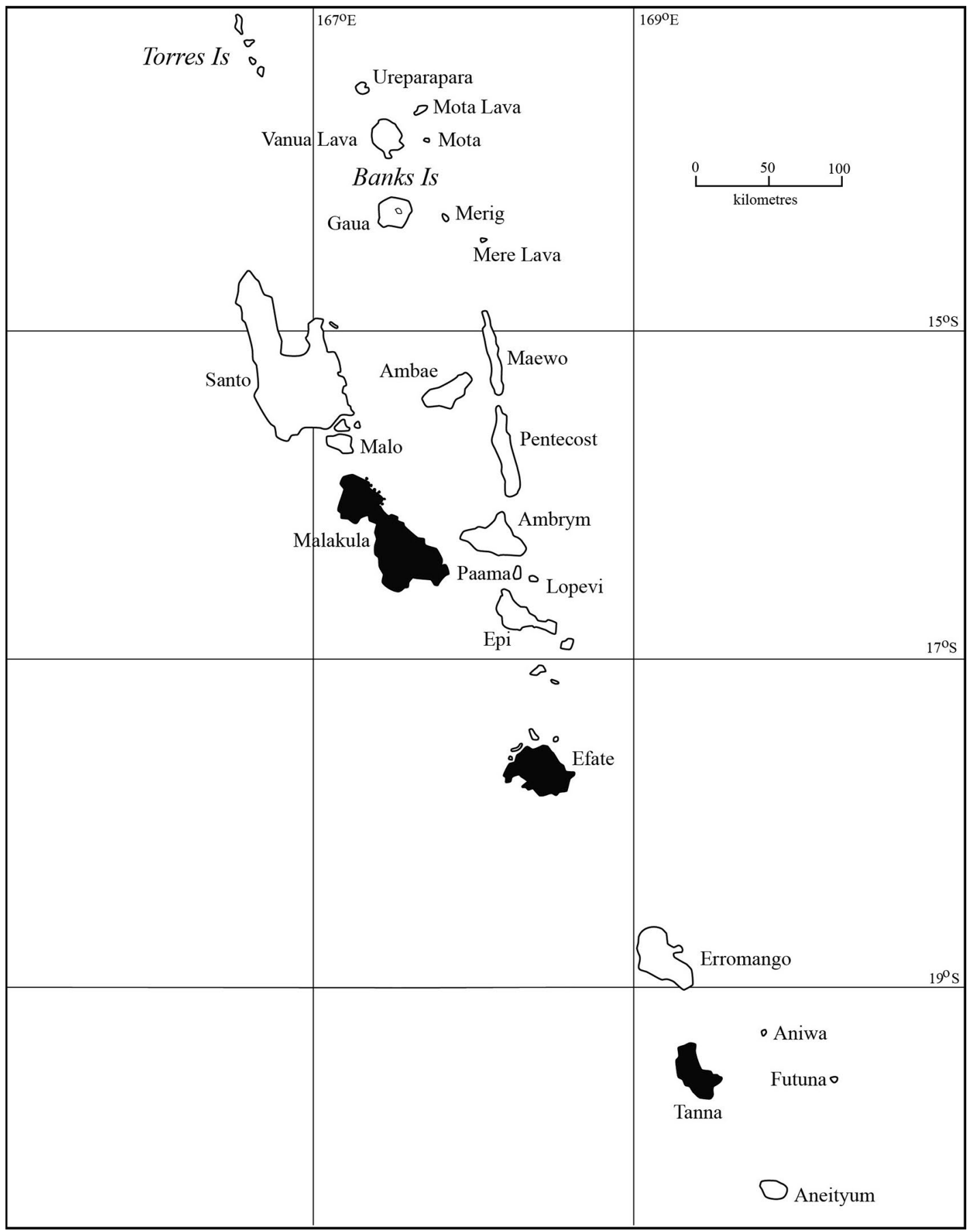

Figure 5.1. Vanuatu archipelago (Malakula, Efate and Tanna infilled).

Source: Stuart Bedford. 
Despite these divisions and their subsequent influence having been repeatedly criticised on a whole series of levels (e.g. Clark 2003; Douglas 1979; Golson 1977; Green 1991; Lilley 1985; Sand 2002; Spriggs 2008; Tcherkézoff 2003; Thomas 1989; see also David and Denham 2006 for a critique of Australian Aboriginal categorisation), they still retain considerable authority, entrenched in the wider public consciousness and in contemporary discourse.

A range of material signals or proxies for social transformation, most often assumed to be associated with increasing social stratification, have been identified from archaeological research in the Pacific. These include population growth; extensive modification of island ecosystems; intensification of agriculture or other productive systems; increased economic specialisation; development of ceremonial or public architecture and increasing territoriality often reflected in more frequent construction of fortifications (Kirch 1984:13-15). Most researchers today agree that there are no universal 'prime movers' in terms of drivers of cultural change but rather a varied combination of environmental contexts and long-term processes influenced by human agency which can produce divergent historical trajectories (Earle 1989; Kirch 2010).

However, discussions of monumentality in general in the Pacific and more specifically monumental architecture in stone, tends to be fixed in association with hierarchically organised chiefdoms, and that such activity would not have occurred if such social frameworks were not in place. These assumptions can clearly be challenged across much of the Melanesian region and very strikingly so in the archipelago of Vanuatu. Various islands in Vanuatu exhibit a similar range of proxies that are associated with social transformation and increasing hierarchy elsewhere, but ultimately arrived at radically different forms of social organisation and expressions of 'monumentality'.

\section{The travelling stones of Malakula}

Malakula is located in the north of the Vanuatu archipelago (Figure 5.1), the second largest island of the group at $2051 \mathrm{~km}^{2}$, along with 15 small islands off its north-east and south coasts (Siméoni 2009:55-61). Its reputation for an island where monumental stone architecture was widely practised has been well known for more than 100 years, to the point where it is often seen as the island's most characteristic cultural feature. Riesenfeld, for example, in his exhaustive tome, The Megalithic Culture of Melanesia, commented that it is no exaggeration to consider Malekula as the best-known place in Melanesia as regards megaliths' (Riesenfeld 1950:35). The ethnographers Speiser, Layard and Deacon, who spent time on the islands in the first part of the 20th century, recorded these sites, generally known as nasara, and associated ceremonial practice in lengthy detail (Deacon 1934; Layard 1942; Speiser 1996). The layout and form of the stone in these structures takes a wide range of forms. In the south, lines or large circles of standing stones tend to be most common, although small dolmens have also been recorded. In some areas, the standing stones are worked into a tubular form. This is seen particularly in the South-West Bay area where a majority of standing stones in any nasara are tubular, but examples can also be found amongst large nasara right up the west coast and into the interior of the north and centre (Figure 5.2a). In the central and northern part of the island, nasara comprise standing stones displaying limited dressing, and stone platforms and tables that are arranged in linear or curvilinear, amphitheatre-like, plan (Figure 5.2b). A very distinctive feature found across the islands in almost all nasara is the marking of a single stone, or in rarer cases several stones, with cupules (Figure 5.2c). Although rarer still, standing stones are also carved with anthropomorphic designs and profiles, an aspect that appears to be more common in the south (Figure 5.2d), although the trading and collecting of these items that has occurred over the last 100 years or more may well have skewed their currently understood distribution. 

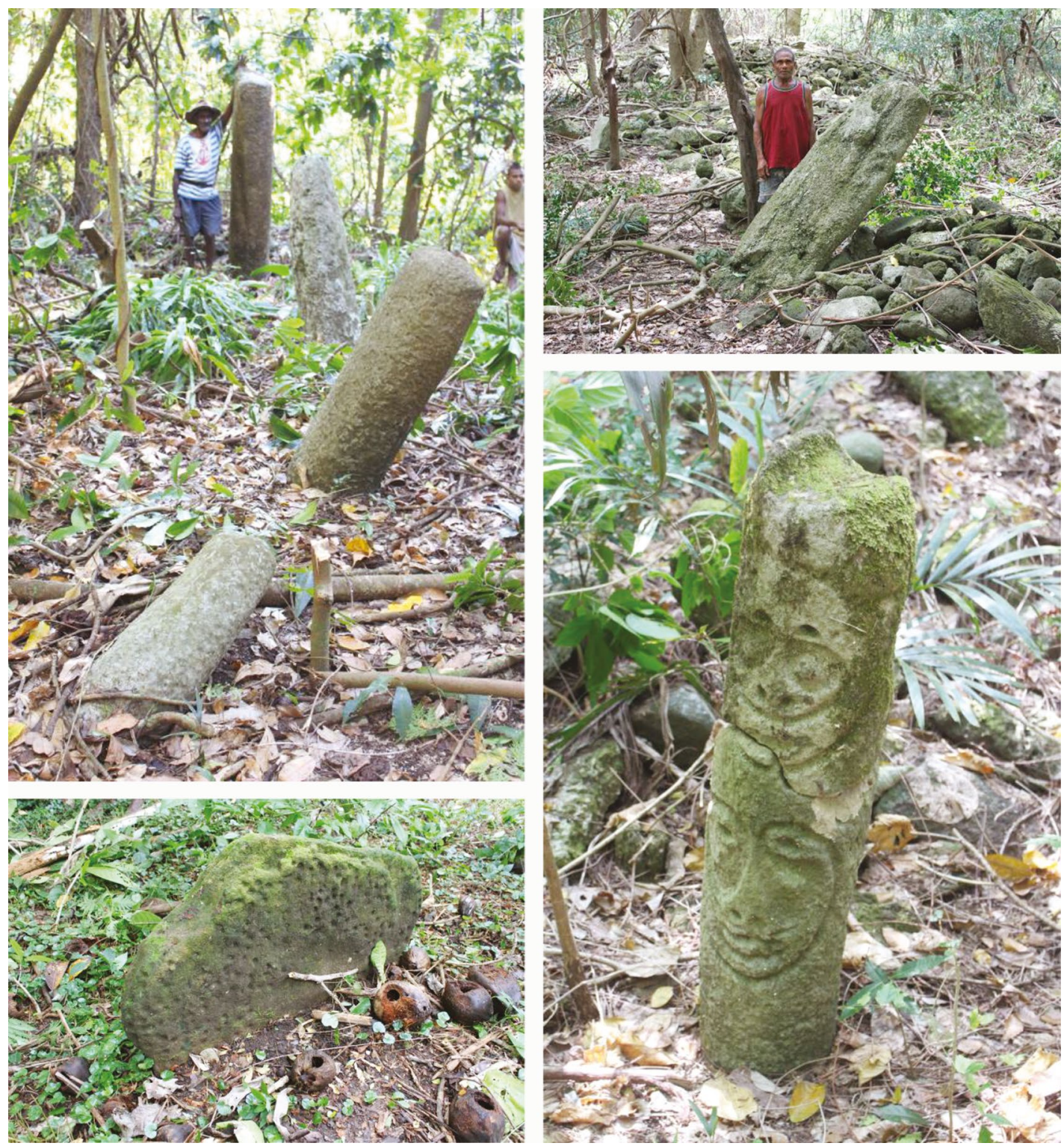

Figure 5.2. Range of stone features found in nasara: (a) tubular standing stones, Vao mainland, north Malakula; (b) stone platforms and standing stones, Tenmiel, north-west Malakula; (c) standing flat slab of beach rock with cupules, Lamap, south-east Malakula; (d) carved tubular standing stone, South-West Bay, Malakula.

Source: Stuart Bedford.

The primary materials that are used in construction are beach rock and limestone from the uplifted reef terraces that are present right up into the interior of the island. Acropora table coral, broken from fringing reefs, has also been used, particularly so in those nasara relatively close to source. They were planted on their side to form wide standing features or sections of wall or more commonly as the flat tops of dolmens or tables (Figure 5.3a). At many of these sites, the beach rock or coral material could be sourced relatively close to hand but even then, the transport and positioning of some of the largest slabs, which might weigh upwards of several tons, would have required significant labour input and engineering skill (Layard 1942:363-408). There are few ethnographic accounts of construction, but Speiser was on the island of Vao when one large slab of beach rock was being hauled to a nasara on a sledge built of logs (see Speiser 1996:Plate 63, 64). 
Although Layard did not witness any of the procedures associated with erecting the stones, he recorded oral traditions associated with nasara construction. It was a complicated and lengthy multi-year process, even for single stones, which involved a whole series of ceremonies at every stage and could involve the participation of labour from nearby villages (1942:363-408).

While much stone could be sourced locally (Layard 1942:417-418), there are almost always stones at these sites that have been sourced from much further afield. For example, the Acropora coral is found associated with dolmens built as shrines in many nasara across the entire central and north of Malakula. In these cases, their transport would have been undertaken across many kilometres and hundreds of metres above sea level. Very large tubular-shaped sections of limestone have been regularly recorded many kilometres from any source, and in one case at one of the highest points $(355 \mathrm{~m})$ in the north of the island (Figure 5.3b). Water-worn stone sourced from rivers on Malakula have also been recorded in nasara on the small islands of the north-east. Further complicating the picture of establishing the origins of stone in any nasara complex was a practice where participants in various ceremonies, including some who had come some distance, would contribute stones themselves. Once erected, particular stones remained associated with that individual who may have participated in ceremonies at a number of nasara over their lifetime (Layard 1942:17).
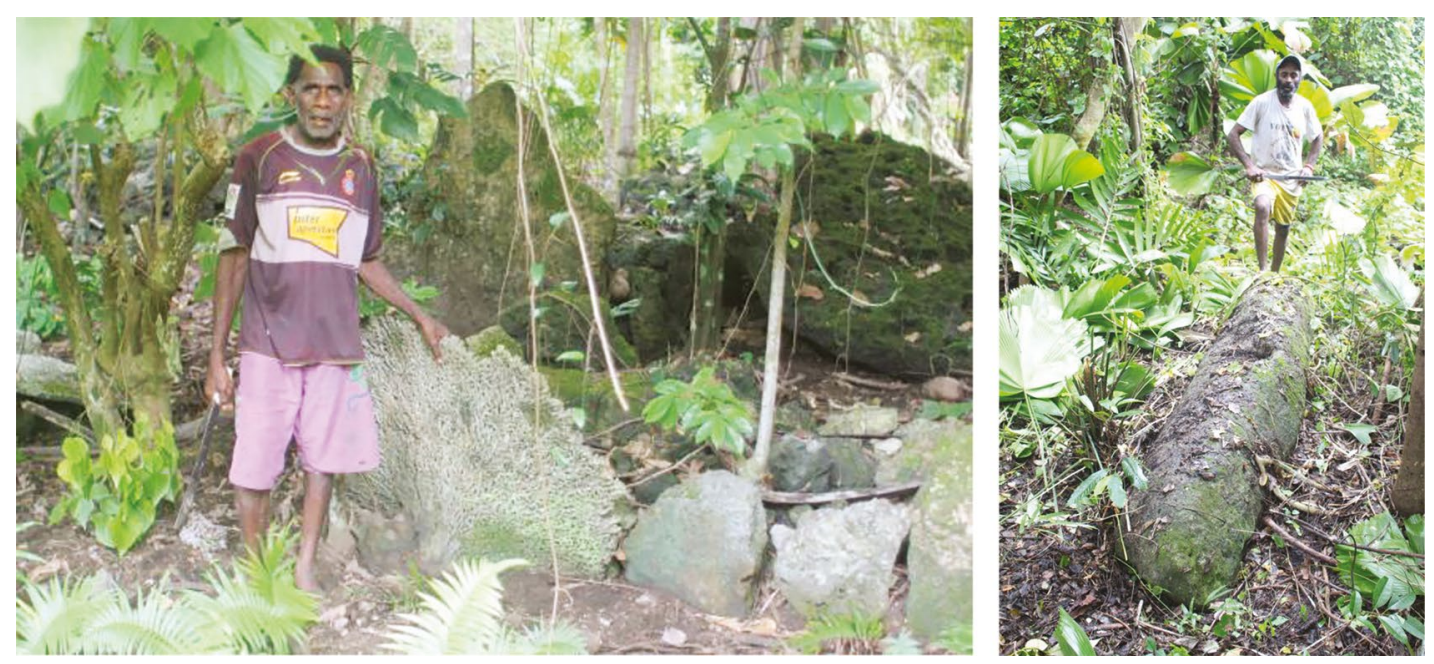

Figure 5.3. (a) Acropora coral sourced directly from the reef and incorporated into the nasara structure, Uripiv Island; (b) tubular stone at nasara on the high point of northern Malakula.

Source: Stuart Bedford.

These nasara sites were central to community life where a whole host of ceremonies took place. The most frequent and most important in terms of local political structure were the grade-taking ceremonies where men attempted to achieve status through ritual and economic tests, rather than hereditary title (Layard 1942:12-19). The chiefly structure on Malakula demonstrated limited hierarchy, certainly in terms of wider community influence, and was only consolidated through the accumulation of grades that involved individuals sponsoring various forms of public ceremony. Grade-taking ceremonies were associated with accumulation and distribution of wealth, most often pigs but also yams. Debt could be accumulated over a generation and organisational aspects of a single ceremony could take 12 months or more to prepare (Bonnemaison 1996; Deacon 1934; Layard 1942). The scale of the largesse associated with these occasions is exemplified by a report from 1892 where 1500 pigs were sacrificed during one ceremony on the small island of Vao, Malakula (population then 2500) (Beaune 1894). 
From the start of the 20th century, increasing depopulation in combination with missionisation generally led to a radical reduction in the number of ceremonies undertaken and in many areas they were discontinued. However, these sites remain durable and highly visible artefacts of ceremony and ritual and represent the material archive containing details of the sociopolitical development of the islands. Even today these ritual structures remain central to peoples' lives, relating to origins, identity and land ownership (Bedford et al. 2017a). In that respect, nasara have retained a continuum of use and a connection with those first generations who established them.

Malakula then, is an island where large ceremonial structures in stone are a widespread feature of the cultural and political landscape, but one that was developed within a minimally stratified social system.

\section{Efate: Monumentality in earth and ceremony}

In contrast, stone architecture was not generally a feature of ceremonial activity on the island of Efate in central Vanuatu. In some cases, standing stones were used to mark chiefly graves but these tended to be few in number and relatively small, no higher than $1 \mathrm{~m}$ above the ground surface (Garanger 1972:Figure 149). However, as demonstrated through the 1960s excavations of José Garanger on the island of Retoka, the use and/or size of stones on Efate is not a reliable marker of ceremonial significance or importance. The 12 small basaltic standing stones (some of which now lie flat) at the site in fact mark the communal burial of more than 50 individuals (Figure 5.4a), who are related to one of the most significant historical ceremonial events on that island for the last 500 years. Apart from these few small standing stones, there was actually very little to be seen on the surface at the site in the 1960s, when excavated, and that remains the case today. The site on Retoka, inscribed in 2008 on the UNESCO World Heritage List, thanks primarily to Garanger's archaeological excavations, is associated with the culmination of a grand ceremony marking the death of the revered high chief Roi Mata in c. 1600 CE (Garanger 1972:59-77). Retoka remains one of the few cultural sites in the Pacific that corresponded to the rich oral traditions (Ballard and Wilson 2012; Garanger 1996).

Roi Mata is credited with introducing peace to the region after an extended period of conflict with his establishment or perhaps reinvigoration of the matrilineal naflak system. According to oral traditions, he became ill at a competitive feast and due to his very high status was buried with followers on the isolated island of Retoka (Ballard and Wilson 2012). This ceremony would have taken considerable time to prepare and involved people from all over Efate and the Shepherd Islands who were prepared to sacrifice a substantial number of high-status individuals as part of the funerary ritual. Grand feasts and displays of largesse would have been intimately associated with this process. 

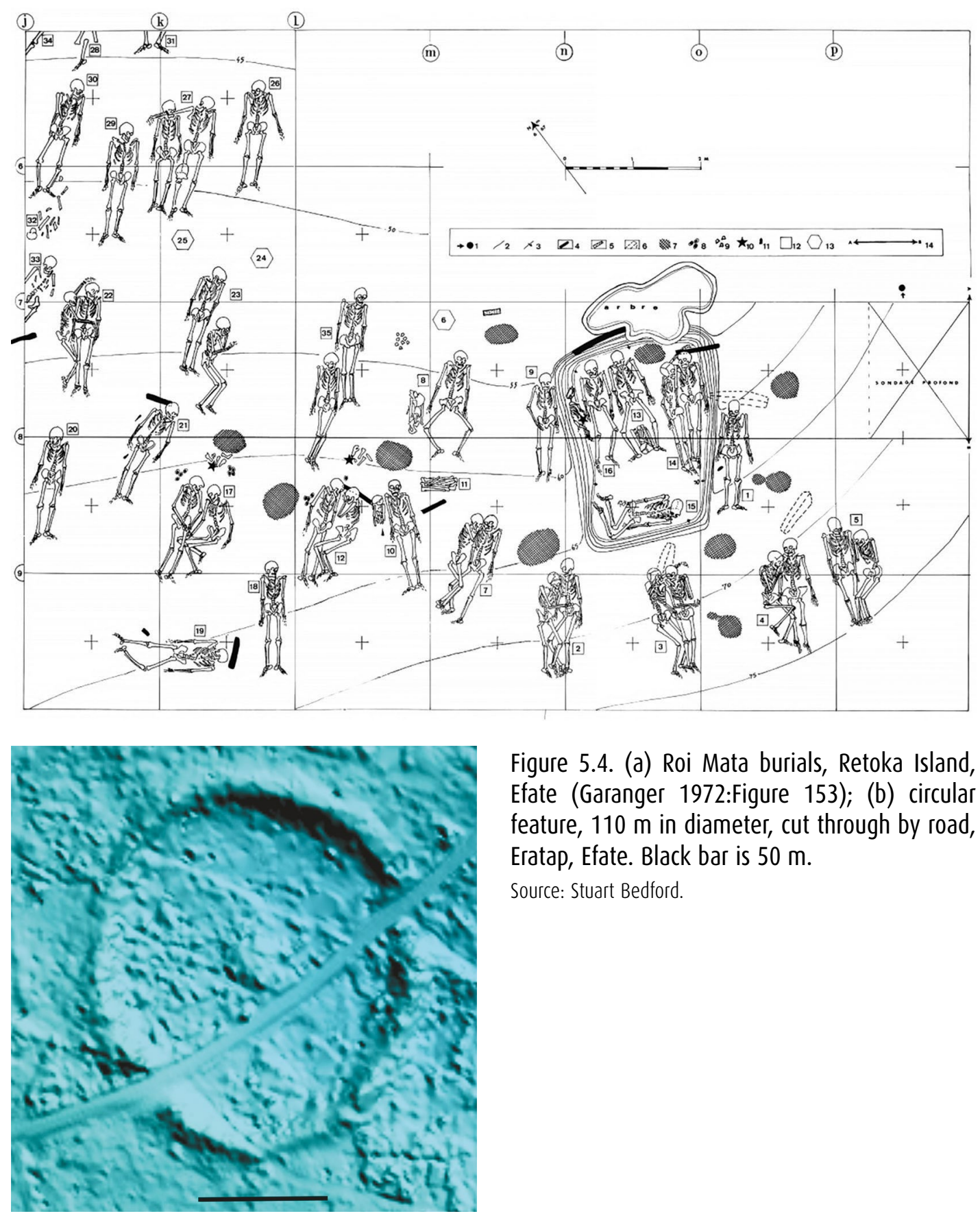

Figure 5.4. (a) Roi Mata burials, Retoka Island, Efate (Garanger 1972:Figure 153); (b) circular feature, $110 \mathrm{~m}$ in diameter, cut through by road, Eratap, Efate. Black bar is $50 \mathrm{~m}$.

Source: Stuart Bedford.

More recent research has identified another very different form of monumentality on Efate. A light detection and ranging (LiDAR) survey of 32.4 per cent of the island has revealed that much of the landscape was completely modified by human activity prior to European contact (Bedford et al. 2017b). Features that dominate the landscape are a range of linear mounds that in some cases extend for several hundred metres or form enclosures of varying size in an irregular mosaic or grid pattern that are associated with agricultural activity. However, the most spectacular and unexpected of these features are massive circular depressions bounded by earth banks (Figure 5.4b). Seventy-one of these circular features have been identified (Bedford et al. 2017b:Figure 2). Their sizes vary greatly but the majority (51) are between 50 and $100 \mathrm{~m}$ in diameter, 15 are between 100 and $145 \mathrm{~m}$ in diameter, and one is substantially larger, at almost $200 \mathrm{~m}$ in diameter. They are found at all altitudes, from $10 \mathrm{~m}$ to $260 \mathrm{~m}$ above sea level, across 
the landscape. They appear to have been formed through soil being shifted from the inside of the feature and out to the exterior. The dimensions of the boundary walls vary, but they are between 1.5-2.0 m high (measured from the interior) and 3-4 m wide. The average diameter of these features is $84 \mathrm{~m}$, a rough calculation of soil displacement for such a feature is more than $33000 \mathrm{~m}^{3} .{ }^{1}$ While interpretation of the circular features remains speculative, they are without doubt truly monumental in terms of their size and the labour input associated with their construction.

What of the chiefly system of Efate? It is very different to that of Malakula in the north as it is essentially characterised by heredity within a hierarchical system where chiefs can exercise considerable authority over their territorial domains. Individuals receive customary names, which is a title within a structure of hierarchical titles (Bonnemaison 1996:212-216). It is also a chiefly system that demonstrates some time depth, as indicated from the oral traditions and archaeological record on Retoka.

Massive depopulation, land alienation and missionisation have all heavily impacted on traditional cultural and political activities on Efate. However, monumentality is clearly seen most visibly today both in the massive earthwork remains across the landscape but also in the 400-year-old ceremony represented by the Roi Mata burials on Retoka that has been preserved within oral traditions.

\section{Tanna: Monumental ritual exchange}

Finally, to the south of the archipelago and the island of Tanna. This is the sixth largest island $\left(570.7 \mathrm{~km}^{2}\right)$ in Vanuatu and one of the most densely populated $\left(46.1\right.$ per $\left.\mathrm{km}^{2}\right)$. Tanna is well known for its retention of aspects of a 'traditional' way of life which revolves around regular all-year-round ceremonies of ritual exchange that encompass all parts of the life cycle and are integral to Tannese social and political life (Bonnemaison 1996:214-216; Lindstrom 1996:123-128). Some of these ceremonies of exchange, based on a system of reciprocity, can take years to prepare, involve thousands of people and abundant displays of largesse, often in the form of pigs and yams (Figures 5.5a and $\mathrm{b}$ ).
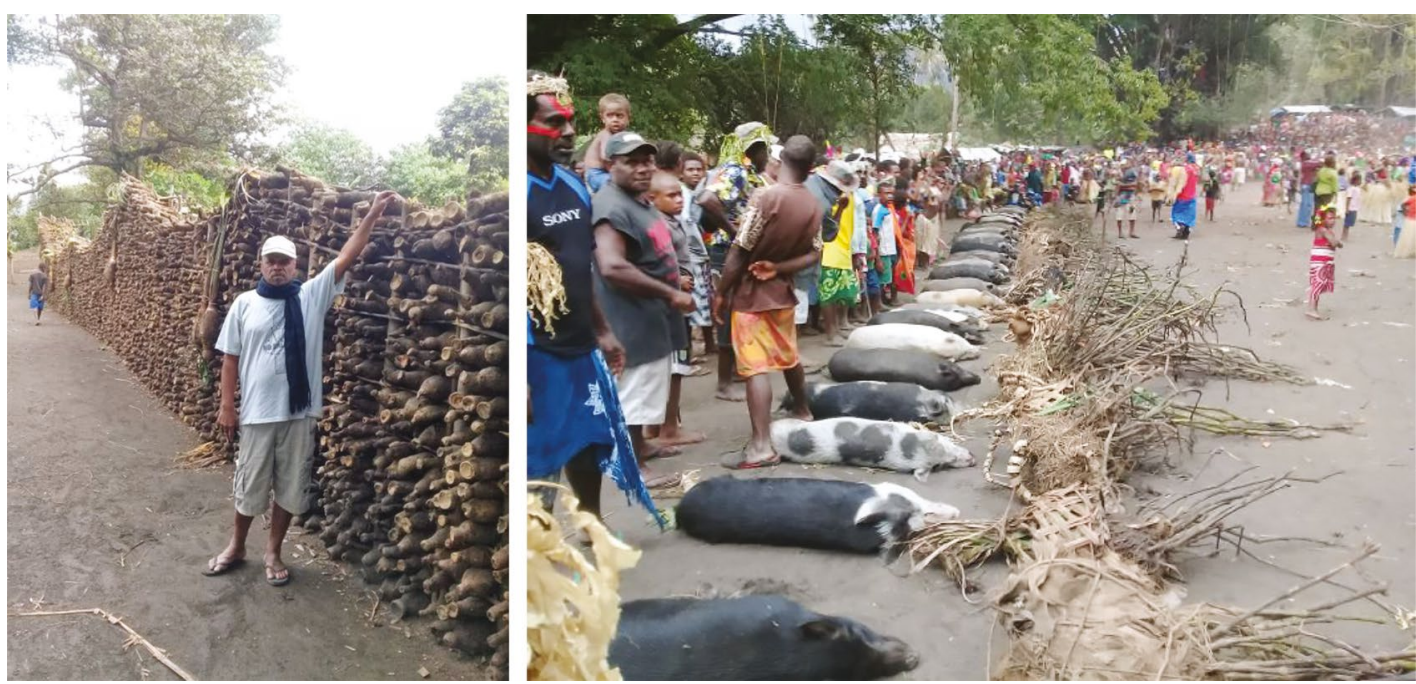

Figure 5.5. Exchange items at a Nial (food exchange) ceremony, Tanna, July 2017: (a) a wall of yams stacked more than $2 \mathrm{~m}$ high; (b) pigs and kava.

1 Volume $=\pi \times 84^{2} \times 1.5=33250.61 \mathrm{~m}^{3}$. This does not take into account the small mound in the centre of most circular features, but the calculation uses the minimal exterior wall height. 
Source: Photographs by Joel Simo.

The population of Tanna is generally scattered across the landscape in small hamlets, with a ceremonial open space of c. 2000-3000 $\mathrm{m}^{2}$ located nearby (Bonnemaison 1994:106-112). These spaces, which are regularly cleaned, generally display nothing exceptional apart from a mature banyan tree on one side of the open area. ${ }^{2}$ However, it is here that the ceremonies of ritual exchange take place, whether they be the nightly exchange of kava between men of the same village or seasonal grand exchanges of agricultural largesse involving a number of tribes that serve to establish or maintain political alliances. Months after these large ceremonies have finished, there is nothing to show but well-stamped open spaces and it is only oral traditions that essentially keep the memory of such events alive. The open space continues to be recognised and restricted as a zone for a range of ongoing ceremonial activities, but beyond the open space and the banyan no other permanent features are added. It is the open space and the repeated ritual exchanges that are the monuments.

The chiefly system on Tanna, although hereditary, is like that of Malakula in that it displays minimal hierarchy and very localised control. James Cook described his initial impressions in relation to the Tannese political structure as follows: 'Chiefs they seem to have amongst them; at least some were announced as such, but they appeared to have little authority over the rest of the people' (Beaglehole 1961:497). However, the apparent egalitarian political nature of the chiefly system on Tanna should not be confused with simplicity, as any claims or conferred rights are open to constant public debate and negotiation and include assessments of individual accomplishment during ritual exchange (Lindstrom 1996:123).

\section{Discussion}

In his summary of traditional Vanuatu political power, Bonnemaison explains that there are very broadly two types of political power found across the archipelago. There are those where chiefdoms are based on a hierarchy of grades and where men come to power through competitive economic display; while the other system is based on heredity and titles. However, he warned against oversimplification, suggesting that neither system was as straightforward as these broad categories might suggest, adding that:

it is as if it were part of the Melanesian genius to take the model it receives, as it spreads from place to place, and complicate it as much as possible to put a local stamp on it. (Bonnemaison 1996:200)

The same complex variation in forms and establishment of chiefly power in Vanuatu is, not surprisingly, also found in the various representations and expressions of monumentality. A common theme related to political power and its material manifestations across the archipelago is in fact diversification. There exists in Vanuatu a range of elements that are seen as proxies for social transformation, that have led to increased hierarchy in other regions of the Pacific: high levels of population density; extensive modification of the ecosystem; development of ceremonial architecture; intensification of agriculture or other productive systems; and in some cases increased economic specialisation. However, the three islands highlighted here, Malakula, Efate and Tanna, all of which display aspects of potential drivers of social transformation, appear to have ultimately arrived at very different forms of social organisation and representations of monumentality. While the three islands hosted regular large ceremonies often involving thousands of people that could take years of preparation, the material legacy of those events is vastly different. Chiefly systems

2 Although there is very limited use of transported or manipulated stone as such in association with any ceremony on Tanna, metaphorical 'stones' are an integral component of Tannese identity and cosmology. They are almost exclusively natural features such as outcrops, mountain tops or ridge crests spread across the landscape (Bonnemaison 1994:116-122). 
on two of the islands demonstrate minimal hierarchy and have very localised influence, yet monuments in the traditional Western sense, large structures in stone, are widespread on one of them. Conversely, the island with the most hierarchical chiefly system demonstrates almost no ceremonial effort with stone.

This extraordinary variation requires some questioning of the whole concept of monumentality in the Pacific. This was a point raised by Chris Ballard and Meredith Wilson, who were instrumental in the inscription of the Roi Mata site on the UNESCO World Heritage List, when they outlined in detail a challenge to the perception of monumentality in the Pacific. They suggest that largely Western concepts that equate monumental only with massive and highly visible construction, almost exclusively using stone, at distinct sites, is misguided. They argue:

Pacific monumentalism is more often located in the elaboration of cosmologies, which are mapped across entire landscapes or seascapes, and which may or may not incorporate what we commonly

define as monuments. (Ballard and Wilson 2014:77)

As illustrated by the data presented in this chapter, this is indeed an aspect that needs to be seriously considered when archaeologists are trying to reconstruct past societies. Highly visible individual monuments often play a central and dominant role in any interpretation of societal complexity, but while this may have some relevance in some parts of the Pacific, it clearly does not in others. In any archaeological interpretation of Pacific societies and their development we must be wary both of European-oriented categories and rigid concepts such as the ladderlike nature of social evolution (Denham 2004; Golson 1977) and the constraints imposed by the 19th-century artificial boundaries of Melanesia, Micronesia and Polynesia (Bedford 2014; Clark 2003).

\section{Conclusion}

While an increasingly sophisticated archaeology investigating social and political transformation has been developed in the Pacific over many decades, it has been strikingly region-specific, primarily focused on Polynesia and, to a lesser extent, Micronesia (Walter and Sheppard 2006). As yet, it remains barely nascent in Melanesia, comprising literally a handful of projects that have explored specialised trading systems, agricultural intensification, and increasing territoriality and social stratification. This dearth of research in Melanesia is due to a whole host of reasons both logistical and theoretical, but it has in many respects perpetuated both the boundaries set out in the 19th century and unilineal evolutionary social-ladder models of historical process. There needs to be a much greater focus on the archaeology of the Melanesian region, beyond Lapita and the Pleistocene, so that we can more fully appreciate the full complexity and diversity of the Pacific region and the diverse routes of societal transformation that have been followed.

\section{Acknowledgements}

Funding for research on Malakula came from an Australian Research Council grant (FT120100716). General thanks are due for the tolerance and collaboration of Malakula communities over two decades and more specifically during a recent project focusing on recording of nasara. Also thanks to James Flexner for presenting a much simpler version of this paper, in my absence, at the World Archaeological Congress meeting in Kyoto in 2016. Joel Simo of the Land Desk at the Vanuatu Cultural Centre provided the photos of the Nial ceremony on Tanna. 


\section{References}

Allen, J. 1985. 'Comments on complexity and trade: A view from Melanesia'. Archaeology in Oceania 20 (2):49-56. doi.org/10.1002/j.1834-4453.1985.tb00102.x.

Ballard, C and M Wilson. 2012. 'Unseen monuments: Managing Melanesian cultural landscapes'. In Managing cultural landscapes, edited by K Taylor and J Lennon, 131-153. London and New York: Routledge.

Ballard, C and M Wilson. 2014. 'Pacific monumentalism'. In Monuments and people in the Pacific, edited by H Martinsson-Wallin and T Thomas, 77-98. Studies in Global Archaeology 20. Uppsala: Department of Archaeology and Ancient History, Uppsala University.

Beaglehole, JC (ed.). 1961. The journals of Captain James Cook on his voyages of discovery: The voyage of the Resolution and Adventure 1772-1775. Volume II. Cambridge: The Hakluyt Society.

Beaune, G. 1894. La terre australe inconnue: Onze croisières aux Nouvelles-Hébrides. Lyon: Delhomme et Briguet.

Bedford, S. 2014. 'Melanesia'. In The Cambridge world prehistory, edited by C Renfrew and P Bahn, 622-631. Volume 1. Cambridge: Cambridge University Press.

Bedford, S, M Abong, R Shing and F Valentin. 2017a. 'From first encounters to sustained engagement and alienation: European and ni-Vanuatu contact from 1774 to 1915, Port Sandwich, Malakula, Vanuatu, Southwest Pacific'. In Historical and archaeological perspectives on early modern colonialism in Asia-Pacific and the Pacific, edited by MC Berrocal and C Tsang, 92-122. Volume 1. Florida: University of Florida Press. doi.org/10.5744/florida/9780813054759.003.0005.

Bedford, S, P Siméoni and V Lebot. 2017b. 'The anthropogenic transformation of an island landscape: Evidence for agricultural development revealed by LiDAR on the island of Efate, Central Vanuatu, South-West Pacific'. Archaeology in Oceania 53 (1):1-14. doi.org/10.1002/arco.5137.

Bickler, S. 2004. 'Prehistoric stone monuments in the northern region of the Kula Ring'. Antiquity 80 (307):38-51. doi.org/10.1017/S0003598X00093248.

Bonnemaison, J. 1994. The Tree and the canoe: History and ethnography of Tanna. Honolulu: University of Hawai'i Press.

Bonnemaison, J. 1996. 'Graded societies and societies based on title: Forms and rites of traditional political power in Vanuatu'. In Arts of Vanuatu, edited by J Bonnemaison, K Huffman, C Kaufmann and D Tryon, 200-216. Bathurst: Crawford House Press.

Byrne, S. 2013. 'Rock art as material culture: A case study on Uneapa Island, West New Britain, Papua New Guinea'. Archaeology in Oceania 48 (2):63-77. doi.org/10.1002/arco.5004.

Clark, G. 2003. 'Shards of meaning: Archaeology and the Melanesia-Polynesia divide'. Journal of Pacific History 38 (2):197-215. doi.org/10.1080/0022334032000120530.

David, B and T Denham. 2006. 'Unpacking Australian prehistory'. In The social archaeology of Australian Indigenous societies, edited by B David, B Barker and I McNiven, 52-71. Canberra: Aboriginal Studies Press.

Deacon, B. 1934. Malekula: A vanishing people in the New Hebrides. London: Routledge and Sons.

Denham, T. 2004. 'The roots of agriculture and aboriculture in New Guinea: Looking beyond Austronesian expansion, Neolithic packages and indigenous origins'. World Archaeology 36 (4):610-620. doi.org/ 10.1080/0043824042000303791. 
Douglas, B. 1979. 'Rank, power, authority: A reassessment of traditional leadership in South Pacific societies'. The Journal of Pacific History 14 (1):2-27. doi.org/10.1080/00223347908572362.

Dumont d'Urville, JSC. 2003. 'On the islands of the great ocean'. Journal of Pacific History 38 (2):163-174. doi.org/10.1080/0022334032000120512.

Earle, T. 1989. 'The evolution of chiefdoms'. Current Anthropology 30 (1):84-88. doi. org/10.1086/203717.

Field, J. 2004. 'Environmental and climatic considerations: A hypothesis for conflict and the emergence of social complexity in Fijian prehistory'. Journal of Anthropological Archaeology 23 (1):79-99. doi.org/ 10.1016/j.jaa.2003.12.004.

Garanger, J. 1972. Archéologie des Nouvelles-Hébrides: Contribution à la connaissance des îles du Centre. Publications de la Société des Océanistes 30. Paris: Société des Océanistes, Musée de l'Homme. doi.org/10.4000/books.sdo.859.

Garanger, J. 1996. 'Tongoa, Mangaasi and Retoka-History of a prehistory'. In Arts of Vanuatu, edited by J Bonnemaison, K Huffman, C Kaufmann and D Tryon, 66-73. Bathurst: Crawford House Press.

Golson, J. 1977. The Ladder of social evolution: Archaeology and the bottom rungs. Sydney: University Press for the Academy of the Humanities.

Green, RC. 1991. 'Near and Remote Oceania_Disestablishing "Melanesia” in culture history'. In Man and a half: Essays in Pacific anthropology and ethnobiology in honour of Ralph Bulmer, edited by A Pawley, 491-502. Auckland: Polynesian Society.

Irwin, G. 1985. The emergence of Mailu. Terra Australis 10. Canberra: The Australian National University.

Kirch, PV. 1984. The evolution of Polynesian chiefdoms. Cambridge: Cambridge University Press.

Kirch, PV. 2010. How chiefs became kings: Divine kingship and the rise of archaic states in ancient Hawai $i$. Berkeley: University of California Press. doi.org/10.1525/california/9780520267251.001.0001.

Layard, JW. 1942. The stone men of Malakula: The small island of Vao. London: Chatto and Windus.

Lilley, I. 1985. 'Chiefs without chiefdoms? Comments on prehistoric sociopolitical organization in western Melanesia’. Archaeology in Oceania 20 (2):60-65. doi.org/10.1002/j.1834-4453.1985.tb00104.x.

Lindstrom, L. 1996. 'Arts of language and space, south-east Tanna'. In Arts of Vanuatu, edited by J Bonnemaison, K Huffman, C Kaufmann and D Tryon, 123-128. Bathurst: Crawford House Press.

Riesenfeld, A. 1950. The megalithic culture of Melanesia. Leiden: E.J. Brill.

Sand, C. 1995. 'Le Temps d'avant' la préhistoire de la Nouvelle-Calédonie. Paris: L'Harmattan.

Sand, C. 2002. 'Melanesian tribes vs Polynesian chiefdoms: Recent archaeological assessment of a classic model of sociopolitical types in Oceania'. Asian Perspectives 41 (2):282-296. doi.org/10.1353/asi. 2003.0010 .

Siméoni P. 2009. Atlas du Vanouatou (Vanuatu). Port Vila: Géo-Consulte Publishing.

Smith, B. 1989. European vision and the South Pacific. Melbourne: Oxford University Press.

Smith, B. 1992. Imagining the Pacific. Melbourne: Melbourne University Press.

Speiser, F. 1996. Ethnology of Vanuatu. An early twentieth century study. Bathurst: Crawford House Press. 
Spriggs, M. 1986. 'Landscape, land use, and political transformation in southern Melanesia'. In Island Societies. Archaeological approaches to evolution and transformation, edited by PV Kirch, 6-19. Cambridge: Cambridge University Press.

Spriggs, M. 2008. 'Ethnographic parallels and the denial of history'. World Archaeology 40 (4):538-552. doi.org/10.1080/00438240802453161.

Tcherkézoff, S. 2003. 'A long and unfortunate voyage towards the "invention" of the Melanesia/Polynesia distinction 1595-1832'. Journal of Pacific History 38 (2):175-196. doi.org/10.1080/0022334032000 120521.

Thomas, N. 1989. Out of time: History and evolution in anthropological discourse. Cambridge: Cambridge University Press.

Thomas, T. 2009. 'Communities of practice in the archaeology of New Georgia, Rendova and Tetepare'. In Lapita: Ancestors and descendants, edited by P Sheppard, T Thomas and G Summerhayes, 119-145. NZAA Monograph 28. Auckland: New Zealand Archaeological Association.

Walter, R and P Sheppard. 2006. 'Archaeology in Melanesia: A case study from the Western Province of the Solomon Islands'. In Archaeology of Oceania: Australia and the Pacific Islands, edited by I Lilley, 137-159. Oxford: Blackwell Publishing. doi.org/10.1002/9780470773475.ch7. 
This text is taken from Archaeologies of Island Melanesia: Current approaches to landscapes, exchange and practice, edited by Mathieu Leclerc and James Flexner, published 2019 by ANU Press, The Australian National University, Canberra, Australia.

doi.org/10.22459/TA51.2019.05 